\title{
Combining multiple isotope and noble gas data with seismic profiles in an interpretation of hydro-geochemical anomalies
}

\author{
Teodora Szocs, ${ }^{1, *}$, and Éva Kóbor Bujdosó ${ }^{1}$ \\ ${ }^{1}$ Mining and Geological Survey of Hungary, Stefánia út 14, 1143 Budapest, Hungary
}

\begin{abstract}
Environmental isotopes $\left(\delta^{18} \mathrm{O}, \delta \mathrm{D}, \quad \delta^{13} \mathrm{C},{ }^{14} \mathrm{C},{ }^{87} \mathrm{Sr} /{ }^{86} \mathrm{Sr}\right)$, combined with hydrogeochemical data and seismic profile interpretation, have been used in studying regional groundwater flow systems in the Pannonian Basin. An interpretation of seismic profiles indicates the existence of faults systems, some of them being traceable from the PreCenozoic basement up to near-surface Quaternary sediments. The Lakitelek study area shows high He contents (22 to $25 \%$ ) of mantle origin, where fault lines might have been reactivated during recent geological times and facilitated the occurrence of mantle-derived $\mathrm{He}$ in the groundwater. The Mezőtúr study area, where most $\mathrm{H}$ - and $\mathrm{O}$-isotope compositions are shifted from the global meteoric water line, exhibits 7.6 to $10.6 \% \mathrm{He}$ of mantle origin,. The deepest sample indicates mixing with formation waters. Here basement faults might not have been reactivated, since they do not seem to have an active role on the groundwater composition and effects of the regional flow system seem to be the dominant factor determining the groundwater isotope compositions.
\end{abstract}

\section{Introduction}

Sustainable water management is a key topic globally, and evaluation of chemical, isotope and noble gas data can substantially contribute to this goal. Water supply is based on groundwater in different percentages across the world, but in many countries it is the major water source. It is used mainly for drinking water and agricultural purposes, but also for industrial and balnaeological usage and, in many cases, it is an essential source for groundwater-dependent ecosystems. Conceptual groundwater flow paths can be defined and then modelled, based on sound geological, geophysical and hydrogeological knowledge. Information on chemical compositions, combined with isotopic and noble gas data, allows the effects of water-rock interaction along flow paths to be identified and can help to define groundwater residence time. Such information is useful not only in defining best management practice for the potential usage, but also in assessing the vulnerability of an aquifer to climate change or pollution.

The Pannonian Basin of central Europe, with its multiple sub-basins, is an important groundwater reservoir, with several of its aquifers being transboundary in nature and used

* Corresponding author: szocs.teodora@mbfsz.gov.hu 
for different purposes. This is also a region undergoing economic development, so there is a need for hydrological studies, especially regarding old groundwater. This study is part of a general hydrogeochemical and isotope survey that has utilized geophysical data interpretation with the aim of better understanding the hydrogeochemical and isotope characteristics of old groundwater in the Great Hungarian Plain sedimentary basin (GHP).

\section{Main hydrogeological characteristics of the Great Hungarian Plain basin}

The GHP basin is up to $7000 \mathrm{~m}$ deep, averaging 2000 to $3000 \mathrm{~m}$, and is a well-studied region both geologically and hydrogeologically. The groundwater reservoir is a multilayered aquifer-system located in an Upper Miocene terrestrial sedimentary succession. The upper part, which is an important drinking water resource, is hosted by Quaternary sediments that have local flow systems superimposed on intermediate and regional flow systems $[1,2]$.

Several publications have investigated the flow systems and the hydrogeochemical and isotope characteristics of the GHP [2-6]. The Zagyva and Nagyalföld Formations (Miocene A) are located in the upper part of this complex, while the lower part comprises sediments of the Újfalu Formation (Miocene B) that hosts the main thermal water aquifer. The intermediate and reginal flow systems in the Quaternary sediments have been recharged during the Pleistocene and contain old groundwater. Recharge to the Upper Miocene Zagyva and Nagyalföld Formations and to the Újfalu Formation took place a few tens of thousands of years ago or earlier, locally affected by upward flow from the deeper Miocene formations or from the basement. The groundwater composition is locally affected by groundwater seepage from Lower Miocene clayey sediments due to overpressure in some parts of the basin.

\section{Results and discussion}

Groundwater samples were collected from operating wells in the GHP during 2014, within the framework of a hydrogeochemical research project of the predecessor to the current Mining and Geological Survey. These water samples were analysed for major chemical constituents, trace elements, environmental isotopes $\left(\delta^{18} \mathrm{O}, \delta \mathrm{D}, \delta^{13} \mathrm{C},{ }^{14} \mathrm{C},{ }^{87} \mathrm{Sr} /{ }^{86} \mathrm{Sr}, \delta^{37} \mathrm{Cl}\right)$ and noble gases $[7,8]$. It was observed that $\delta^{18} \mathrm{O}$ and $\delta \mathrm{D}$ data are shifted away from the Global Meteoric Water Line (GMWL) [9] and lie on or close to the local meteorological water line (LMWL) [10], except for waters at two locations (at Szarvas and Mezőtúr), which are enriched in ${ }^{18} \mathrm{O}$ through mixing with formation waters.

This survey also confirmed that the aquifers studied host groundwaters with ${ }^{14} \mathrm{C}$ values mostly less than $2 \mathrm{pmC}$ that are part of intermediate and regional flow paths. The residence times in these groundwater flow paths are on the scale of a few ten thousand years or more. Dating by ${ }^{81} \mathrm{Kr}$ is needed (and planned) to detect and estimate residence times for water with ${ }^{14} \mathrm{C}$ activities around the ${ }^{14} \mathrm{C}$ dating limit since large, regional groundwater flow paths in the GHP have already been numerically modelled [2].

A chemical anomaly is suggested at Lakitelek by the fact that groundwater at a depth of approximately $1000 \mathrm{~m}$ depth has a low total dissolved solids (TDS) value of $\sim 650 \mathrm{mg} / \mathrm{l}$ compared with higher TDS values of 1000 to $1450 \mathrm{mg} / \mathrm{l}$ for waters in the $\sim 550$ to $790 \mathrm{~m}$ depth interval. This water has an unusually high ${ }^{87} \mathrm{Sr} /{ }^{86} \mathrm{Sr}$ ratio $(0.712)$ and is the most ${ }^{37} \mathrm{Cl}$ depleted of the 19 samples analysed. A modelling study of the thermal anomaly at Tiszakécske [11], located near Lakitelek, has concluded that thermal convection in the upper $1000 \mathrm{~m}$ might be the cause of this anomaly. This study proposed that either the 
temperature profile of a 1500 to $2000 \mathrm{~m}$ deep well along the downward side of the convection or interpretation of a seismic profile crossing this zone could clarify whether there is a thermal convection in the deeper depths or the anomaly is caused by upward groundwater flow along a fracture zone. Although no sample collected in Lakitelek for noble gas analysis in 2014, former studies [12] suggested the presence of mantle-derived based on the presence of helium enriched in ${ }^{3} \mathrm{He}$ compared to crustal derived ${ }^{4} \mathrm{He}$.

In order to explain the anomalies in the chemical and isotope data, further sampling including samples for noble gas analysis was carried out between 2015 and 2017, giving a denser distribution of data. The new groundwater analysis for noble gases (methods presented in [13]) in the Lakitelek region observed high $(1.4$ to 1.6$){ }^{3} \mathrm{He} /{ }^{4} \mathrm{He}$ isotope ratios and indicates that about 22 to $25 \%$ of $\mathrm{He}$ is of mantle origin. Contributions of mantle $\mathrm{He}$ have also been detected in other parts of the Pannonian basin $[8,13,14]$.

\subsection{Combining seismic profile interpretations with isotope and noble gas analysis}

Beside the new groundwater samples discussed above, two key locations were selected to investigate whether the existence of potential faults or fault zones might be present that might cause noble gas and stable isotope anomalies. Geophysical studies were undertaken to interpret archived seismic profiles of the Mining and Geological Survey using Landmark Seismic Interpretation software. Seismic profiles, where faults from tectonic events were identified, have been investigated at Lakitele (2-D) and Mezőtúr (2-D and 3-D). Two representative profiles from Lakitelek and one from Mezőtúr have been chosen from which to interpret the geological environment.

Geological descriptions and geophysical core descriptions of boreholes in a 1-2 km wide zone along the seismic profiles were used to support this effort. As shown in Figure 1 , several fault lines can be identified in the Lakitelek region which might have been reactivated during geological times and which can be conducive to the occurrence of high mantle origin helium. Two major surfaces have been identified. The boundary between the Lower and the Upper Pannonian Formations (Upper Miocene) sediments marked with yellow, and the bottom of the pre-Cenozoic basement marked with purple lines. Faults belonging to horizontal dislocations are marked with red lines, blue lines show the tectonic elements which belong to the Cretaceous nappe-type movements, and purple colours show the other unspecified tectonic elements. A NW-SE fault zone of a horizontal dislocation could be identified on the bottoms of the Tertiary sediments. The horizontal dislocation could be identified even within the Upper Pannonian (Pliocene) sediments.

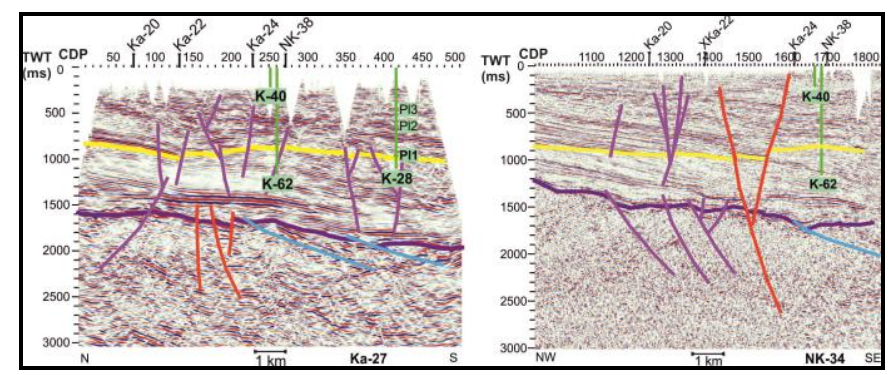

Fig. 1. Seismic profiles for the Lakitelek region. Left side: seismic section Ka-27 in approximately NS direction. Right side: Seismic section for NK-34 in approximately NW-SE direction (CDP: Common Depth Point, TWT (ms): Interpreted horizons from 2-way travel times - purple: top of PreCenozoic basement, yellow: boundary of Lower and Upper Pannonian Formations; Interpreted faults: blue: Cretaceous blanket motion, red: horizontal motion, purple: other younger faults). 

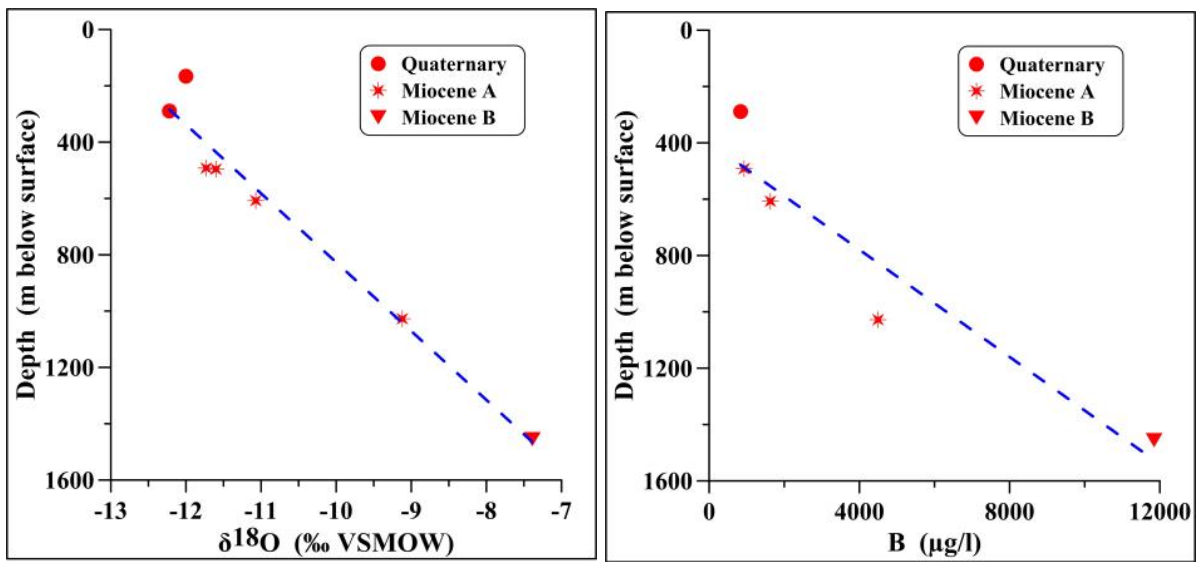

Fig. 2. Depth profiles for $\delta^{18} \mathrm{O}$ (a) and B concentration (b) for the central Pannonan Basin.

While $\mathrm{He}$ of mantle origin varies between (7.6 to $10.6 \%$ ) in the Mezőtúr region, a groundwater sample from 1430 to $1480 \mathrm{~m}$ depth is enriched in ${ }^{18} \mathrm{O}$, with a $\delta^{18} \mathrm{O}$ value of $7.4 \%$ VSMOW. The shallower Pleistocene aquifer, which was investigated with wells screened in the 160 to $300 \mathrm{~m}$ depth interval, hosts low- ${ }^{18} \mathrm{O}$ groundwater which has been infiltrated during the Pleistocene $\left(\delta^{18} \mathrm{O}=-12.2\right.$ to $-12.0 \%$ VSMOW). As shown in Figure 2., waters from the deeper Upper Pannonian formation into the direction of the shallower Pleistocene aquifer exhibit $\delta^{18} \mathrm{O}$ values that are less and less enriched in ${ }^{18} \mathrm{O}$.

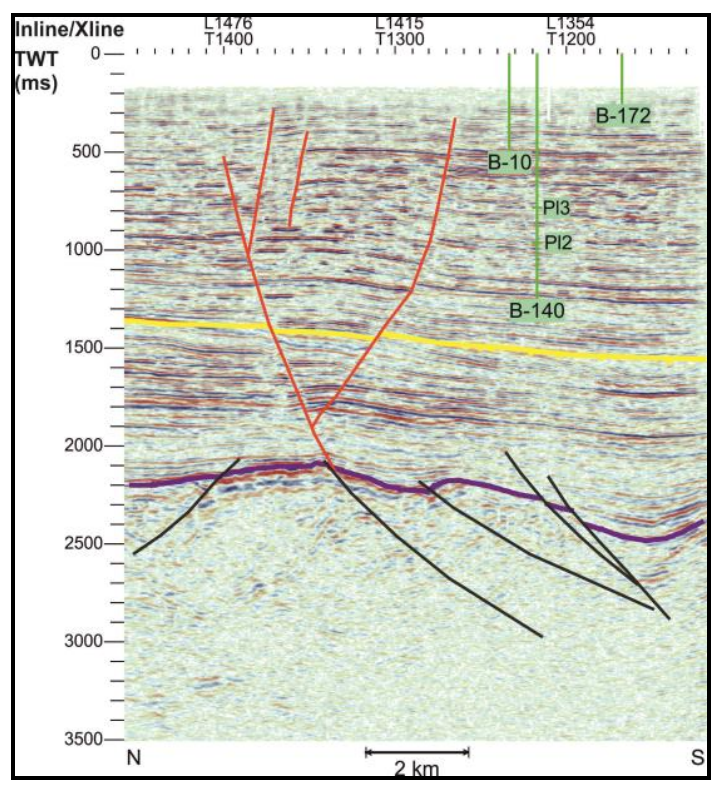

Fig. 3. Seismic profiles in the Mezőtúr region (TWT (ms): Interpreted horizons from 2-way travel times - purple: top of Pre-Cenozoic basement, yellow: boundary of Lower and Upper Pannonian Formations; Interpreted faults: red: horizontal motion, black: other younger faults).

With the exception of data from two archival samples, groundwater $\delta \mathrm{D}$ and $\delta^{18} \mathrm{O}$ values are shifted below the GMWL and four samples lie on or near a LMWL, with $\delta \mathrm{D}=7.9 \delta^{18} \mathrm{O}$ +3.9 [7]. The significant displacement of the sample from the 1430-1480 m depth below both the GMWL and the LMWL indicates mixing with formation waters from hydrocarbon 
bearing reservoirs [7]. Former studies and the potential values show that this area is a discharge zone for the regional flow systems. A pattern similar to the $\delta^{18} \mathrm{O}$ data distribution can be observed for example in the $\mathrm{B}$ concentration profile, indicating mixing with formation waters (Fig. 2).

From the seismic profile in Figure 3, it is seen that the boundary of the Upper and Lower Pannonian Formations, as well as the top of the Pre-Cenozoic basement, is significantly lower in the Mezőtúr area compared to the Lakitelek region. There are characteristic fault lines, which can be followed up to the near surface, but they are further from the surveyed wells. These faults may result in a more closed fault structure.

\section{Summary}

Both the Lakitelek and the Mezőtúr study area show anomalies in their hydrogeochemisty and isotopic and noble gas data compared to the surrounding areas. These anomalies cannot be explained only by changes due to water rock interactions along the flow paths, but by their different position in the regional flow systems and the geological structure. At Lakitelek the potential effect of the fault systems has been demonstrated, supported also by the seismic profiles presented here, resulting in about 22 to $25 \%$ mantle-derived $\mathrm{He}$ in the groundwater. In the Mezőtúr area, where only up to $10.6 \%$ mantle-derived $\mathrm{He}$ was detected, the discharge zone of the regional flow system is considered to be the dominant factor determining the groundwater composition rather than the fault lines.

\section{References}

1. M. Erdélyi, Hidrol közlöny, 4, 147-156 (1975)

2. M. Stute, J. Deák, Radiocarbon, 31, 902-918 (1989)

3. I. Varsányi, L. Ó.Kovács, Chem Geol, 264, 187-196 (2009)

4. I. Varsányi, et al., App Geochem, 26, 91-104 (2011)

5. J. Mádl-Szőnyi, J. Tóth, Hydrogeol J, 17, 961-980 (2009)

6. S. Simon, et al, Hydrogeol J, 19. 3, 701-717 (2011)

7. T. Szocs, et al., Proc Earth Planet Sci, 13, 177-180 (2015)

8. T. Szocs, et al., Proc Earth Planet Sci, 17, 877-880 (2017)

9. H. Craig, Science, 133, 1702-1703 (1961)

10. J. Deák, VITUKI zárójelentés. Budapest (1995)

11. L. Lenkey, Magyar Geofiz, 34, 30-45 (1993)

12. D.J. Martel, et al., Nature, 342, 908-912 (1989)

13. L. Palcsu, et al., Mar Petrol Geol, 54, 216-227 (2014)

14. K. Bräuer, et al., Chem Geol, 422, 60-70 (2016) 